\title{
TEOLOGI PEMBEBASAN: GERAKAN FEMINISME KRISTEN DAN PENDEKATAN DIALOG MARTIN BUBER
}

\author{
Yahya Afandi
}

\begin{abstract}
It cannot be denied that the presence of feminist liberation movements and theology has left such a profound influence on the history of the paradigm shift of the church even more into the wider scope. The theology of feminism has also correctly demonstrated the general failure of men in fulfilling God's plan regarding the purpose of his creation, since love in a husband-wife life is described as Christ loves to His church. The next positive contribution of the theology of liberation of feminism has also stood against the practice of oppression, humiliation, manipulation and even the exploitation of women.

It should be noted, however, that in addition to the great contributions that can even trigger a paradigm shift, feminist movements and theology also leave problematic traces. This Christian feminist flow moves in a Christian framework but their method of feminism and theology approach generally entirely uses a liberal perspective. On the one hand they assume that this developed theology comes from the inspired word of God, but on the other hand they step out of the orthodoxy of traditional Christian faith. One of the terms used to respond to feminist movements and theology is that they apply "hermeneutic of suspicion". This means that systematically they assume that the writers of books of the Bible that are generally men, as well as their interpreters deliberately cover the role of women in the era of early Christianity. Also they attempted to abolish the cultural system which is the hallmark of society in the time of writing holy books, the patriarchy that can be matched by the demythologization of Bultmann. This method of exegesis is characterized by Heidegger's existential understanding that is firmly attached to the spirit of feminists in their struggle for rights and ideals. Strictly speaking such a view is certainly far from the biblical truth. If feminists believe that the Bible contains many mistakes but why then they also use them as the basis of authority for their theological principles. It is unfortunate that, on the other hand, this feminist movement must take extreme measures such as sacrificing orthodox Christian principles and tend to be liberal. Martin Buber's view on the importance of dialogue between the sexes proved to provide a way out of the danger of the continued practice of male domination over women; but also preventing women from the risk of extreme feminist liberation movements.
\end{abstract}


Keywords: Christian, Feminist, Liberation, Theology, hermeneutic, suspicion, Method Correlation.

\section{Pendahuluan}

"Gadis itu kini telah berusia 12,5 tahun. Waktu telah tiba baginya untuk mengucap selamat tinggal pada masa kanak-kanak. Dan meninggalkan bangku sekolah, tempat dimana ia ingin terus tinggal... Dengan menangis-nangis ia memohon kepada ayahnya agar diijinkan untuk turut bersama abang-abangnya meneruskan sekolah ke HBS di Semarang. Ia berjanji akan belajar sekuat tenaga agar tidak mengecewakan orang tuanya. Ia berlutut dan menatap wajah ayahnya. Dengan berdebar-debar ia menanti jawab ayahnya yang kemudian dengan penuh kasih sayang membelai rambutnya yang hitam... 'Tidak!' jawab ayahnya lirih dan tegas..." 116

Menyimak petikan tulisan R.A. Kartini di atas, dapat disaksikan betapa potret eksistensi kaum perempuan tengah berada dalam situasi yang tidak semestinya sebagaimana Allah dalam Alkitab merencanakan kehadirannya di sebelah kaum laki-laki. Tujuan Ilahi atas diciptakanNya makhluk paling mulia, disebut manusia dengan gender 117 yang berbeda tersebut telah sekian waktu bergeser bahkan terdapat kecenderungan untuk saling mendominasi. Bruni menjelaskan bahwa pergeseran ini merupakan akibat dari peristiwa kejatuhan manusia ke dalam dosa yang telah menghancurkan hubungan dengan Allah dan sesama.

Khususnya dominasi laki-laki terhadap perempuan merupakan penyimpangan nyata terhadap prinsip mula-mula sebagai entitas

116 Penggalan salah satu surat R. A. Kartini kepada seorang perempuan Belanda bernama Nyonya Abendanon, kala itu Kartini berusia 12,5 tahun, pada tahun 1892, ketika ia harus meninggalkan bangku sekolah secara paksa karena harus memasuki "pingitan" (persiapan khusus bagi kaum perempuan untuk memasuki masa pernikahan). Dalam surat ini Kartini memakai kata ganti orang ketiga tunggal untuk menggambarkan dirinya. Surat ini bernuansa kesedihan hati seorang perempuan yang terbatasi hak dan suaranya di bawah tekanan budaya Patriaki Jawa. Dhimas Wisnu Mahendra, "Mengenal dan Memahami Pemikiran Ibu Kita Kartini Melalui Tulisan-tulisannya," 20 April 2012 [Artikel on-line]; available from http://sosok.kompasiana.com/2012/04/20/mengenal-dan-memahami-pemikiran-ibu-kita-kartini-melalui-tulisantulisannya-456880.html; internet; diakses pada tanggal: 25 Oktober 2017.

117 Gender adalah suatu sifat yang melekat pada kaum perempuan dan laki-laki, yang dikonstruksikan secara sosial maupun Kultural. Ini amat berbeda dengan konsep “jenis kelamin” yang lebih berkonsentrasi pada anatomi biologi manusia dan memang telah ditentukan secara terberi (given). Mansour Fakih, Analisis Gender dan Transformasi Sosial (Yogyakarta: Pustaka Pelajar, 1997), 7. 
komunitarian berdasarkan reciprocity dan equality “'ezer knegdo," Kej.

2:18.118 Kesegambaran antara manusia dan Sang Pencipta terlihat dalam hubungan antara seorang laki-laki dan perempuan, yaitu kesanggupan untuk berbagi dalam relasi resiprokal. Esensi dari hubungan resiprokal tersebut secara unik jelas melalui terminologi Ibrani 'ish dan 'isha; serta istilah dalam bahasa Inggris man dan wo[man] yang tidak terlihat dalam bahasa Indonesia.119

Dalam tulisan Fiorenza, salah satu motor gerakan Feminisme Kristen menggambarkan keberadaan kaum perempuan di tengah dominasi kaum laki-laki:

We are the "other," socialized into helpmates of men or sex objects for their desire. Journals, advertisements, television, and movies represent us either as dependent little girls (e.g., to address "baby"), as sexy and seductive women, or as self-sacrificing wives and mothers. Teachers, psychologists, philosophers, writers, and preachers define us as derivative, inferior, and subordinate beings who lack the intelligence, courage, and genius of men. 120

Tulisan Fiorenza tersebut sejalan dengan analisis tajam Stott tentang praktik perbedaan gender, “...They [kaum perempuan] have often been treated as mere playthings and sex objects, as unpaid cook, housekeepers and child-minders.... their gifts have been unappreciated, their personality smothered, their freedom curtailed, and their sevices in some areas exploited, in others refused." 121

Lebih jauh, fakta kekerasan terhadap perempuan telah mendorong Komnas. Perempuan mendesak pemerintah Indonesia untuk mengesahkan rancangan undang-undangan penghapusan kekerasan seksual dengan memperhatikan "Perlindungan Korban" melalui kegiatan kampaye enam

118 Luigino Bruni, The Genesis and Ethos of the Market (New York: Palgrave Macmillan, 2012, 19. 119 Ibid.

120 Elizabeth Schüssler Fiorenza, Feminist Theology As A Critical Theology of Liberation (University of Notre Dame, $\mathrm{tt}$ ), 607; [Artikel on-line]; available from http://www.ts.mu.edu/readers/content/pdf/36/36.4/36.4.2.pdf ; internet; diakses pada tanggal: 30 Oktober 2017. 121 John Stott, Issues Facing Christians Today: New Perspectives on Social and Moral Dilemmas (London: Marshall Pickering, 1990), 254. 
belas hari anti kekerasan terhadap perempuan yang diperingati sejak tanggal 25 November hingga 10 Desember pada setiap tahunnya.122 Mereka bahkan mencatat dan memperkenalkan terminologi khusus terhadap tindak kekerasan melalui media sosial dan maupun persekusi moral hingga menghilangkan nyawa perempuan berbasis gender yaitu femicide (femisida). 123

Dalam konteks kebudayaan masyarakat Jawa sebagai latar kultural R. A. Kartini, kaum perempuan menjadi "the second sex" (suatu konsep subordinansi yang terus-menerus dibangun oleh masyarakat patriaki; padahal Tuhan sendiri tidak pernah menjadikan perempuan sebagai makhlukNya yang memiliki kelas kedua dan kehadirannyapun bukan semata-mata sebagai pelengkap kaum laki-laki), sehingga pada akhirnya kaum perempuan kurang memiliki akses peningkatan kualitas hidup, pendidikan, ekonomi, sosial, politik dan bidang-bidang lainnya.124 Bertolak dari berbagai wujud pengalaman subordinansi gender tersebut, maka lahirnya sebuah gerakan pembebasan merupakan sebuah mimpi besar kaum perempuan.

Di lain sisi ada fakta meningkat-pesatnya peranan kaum perempuan dewasa ini, di mana kehadiran serta keterlibatan mereka Nampak begitu menonjol dalam kancah perpolitikan dunia, termasuk di Indonesia. Data yang diperoleh dari Inter Parlementary Union, menempatkan Indonesia dalam urutan kedua setelah sebelumnya yaitu pada data tahun 2013 berada pada urutan keempat tentang partisipasi kaum perempuan dalam dunia politik dibandingkan negara-negara di lingkup Asia Tenggara.

122 Sahkan RUU Penghapusan Kekerasan dengan Memperhatikan Perlindungan Korban Seksual dengan Memperhatikan Perlindungan Korban, [Artikel on-line]; available from

https://www.komnasperempuan.go.id/reads-peluncuran-kampanye-16-hari-anti-kekerasan-terhadap-perempuantahun-2017 ; Internet; diakses pada tanggal: 24 November 2017.

123 Contoh yang paling menyolok dari tindak "Persekusi Moral" yang menghakimi perempuan dalam bentuk penganiayaan seksual (penggrebekan, penelanjangan dan diarak di depan umum) yang membuat korban perempuan mengalami trauma berkepanjangan dan merupakan sinyal buruk penghakiman pada perempuan melalui agresi berbasis ketubuhan. Ibid. LkiS, 2003).

124 Ismail Nurjanah, Perempuan dalam Pasungan: Bias Laki-laki dalam Penafsiran (Yogyakarta: 
Inter Parlementary Union 125

\begin{tabular}{|l|c|c|c|c|}
\hline Nama Negara & $\begin{array}{c}\text { Tahun } \\
\text { Pemilu }\end{array}$ & $\begin{array}{c}\text { Jumlah } \\
\text { Kursi }\end{array}$ & $\begin{array}{c}\text { Kursi } \\
\text { Perempuan }\end{array}$ & Prosentase \\
\hline Viet Nam & 2016 & 494 & 132 & $26.7 \%$ \\
\hline Indonesia & 2014 & 560 & 111 & $19.8 \%$ \\
\hline Myanmar & 2015 & 433 & 44 & $10.2 \%$ \\
\hline Malaysia & 2013 & 222 & 23 & $10.4 \%$ \\
\hline Thailand & 2014 & 250 & 12 & $4.8 \%$ \\
\hline Singapore & 2015 & 100 & 23 & $23.0 \%$ \\
\hline Timor-Leste & 2017 & 65 & 21 & $32.3 \%$ \\
\hline
\end{tabular}

Sejak zaman penjajahan hingga kini, sejak era perjuangan bangsa hingga pembangunan dan reformasi, peran kaum perempuan tidak dapat dianggap sepi. Informasi sejarah, yaitu pada masa sebelum kemerdekaan telah lahir gerakan yang menyadarkan arti penting perempuan dalam keikutsertaan mereka dalam organisasi kebangsaan. Bahkan dalam kongres perempuan Indonesia II, melahirkan "hak pilih pasif" (pasief kiesrecht) kaum perempuan. 126

Uraian di atas sangat bernuansa positif, meskipun di sisi lain masih terdapat sejarah perjuangan yang belum tuntas dan terus diperjuangkan tentang hak kaum perempuan melalui berbagai wujud "gerakan feminisme," dari sekadar memendam perasaan tidak puas hingga aktivitas yang terbilang ekstrim. Gerakan pembebasan (liberation movements) umumnya bersifat menentang kebudayaan yang telah kuat berakar dalam sistem kemasyarakatan secara luas. Dan dari waktu ke waktu, pengaruh gerakan ini makin menguat khususnya dalam beberapa dasawarsa terakhir abad ke20, yang tidak dapat dinafikan telah membuahkan berbagai perubahan amat mendasar dalam tatanan hidup bermasyarakat.127 Tak pelak gerakan ini turut berdampak terhadap perkembangan dunia teologi abad ke-20, khususnya pada paruh kedua tahun 60an, yaitu munculnya para ahli

125 Daftar negara-negara ini pilih secara khusus untuk lingkup ASEAN. Sumber: Inter Parlementary Union (http://www.ipu.org/wmn-e/classif.htm), diakses pada tanggal: 24 November 2017.

126 Ester Mariani Ga, "Partisipasi Politik Perempuan : Antara Kewajiban dan Perjuangan Memperoleh Hak, Bina Darma” 1997, [Artikel on-line]; available from http: isjd.pdii.lipi.go.id/admin/journal/5415978996.pdf; Internet; diakses pada tanggal: 24 November 2017.

127 Francis Martin, The Feminist Question: Feminist Theology in the Light of Christian Tradition (Grand Rapids: Eerdmans, 1994), 156. 
teologi perempuan yang juga mencoba mengembangkan genre teologi feminisme.128 Gerakan feminisme secara faktual ternyata tidak hanya berkembang dalam dunia Kristen, melainkan juga di beberapa aliran kepercayaan lain termasuk Buddisme, Hinduisme, Yudaisme, Islam, dan lain-lain.129

Mengenai apa yang dimaksud dengan gerakan dan teologi feminisme Kristen; mengapa dalam perjalanan waktu terdapat berbagai tanggapan bahkan reaksi yang berbeda-beda demi membenarkan eksistensi gerakan ini; apakah terdapat rujukan atau kecukupan dukungan dari sumber berotoritas, dan bagaimana seharusnya usaha rekonsiliasi yang dapat dirintis demi terciptanya komunitarian berdasarkan reciprocity dan equality yang telah lama hilang, akan dibahas secara ringkas dalam tulisan berikut ini.

\section{Latar Belakang Gerakan Feminisme Kristen}

Karakter yang amat menonjol dari gerakan feminisme adalah mereka lahir sebagai bentuk protes terhadap praktek subordinansi gender dan diskriminasi kaum perempuan yang telah terjadi selama berabad-abad, baik yang terjadi di luar maupun di dalam gereja Kristen. Intinya gerakan feminisme meletakkan penekanan pada tiga isu utama yaitu: penindasan, patriaki dan perjuangan kesetaraan hak.130 Dalam lingkup Kristen terdapat tokoh-tokoh seperti Rosemary Radford Ruether, Letty M. Russell dan Elizabeth Schüssler Fiorenza, dan lain-lain umumnya mereka berasal dari tradisi Kristen Liberal. Grenz dan Olson 131 menjelaskan bahwa pada era 60an lahir tiga arus pergolakan teologis yang amat berdampak bagi

128 Stanley J. Grenz \& Roger E. Olson, Twentieth Century Theology (Downers Grove: InterVarsity, 1992), 225.

129 Feminist Theology, [Artikel on-line]; available from http://en.wikipedia.org/wiki/Feminist theology; Internet; diakses pada tanggal: 25 November 2017, band. David L. Smith, A Handbook Contemporary Theology: Tracing Trends \& Discerning Directions in Today's Theological Landscape (BridgePoint, 1992) 244.

130 Denise L. Carmody mencatat, "By feminism I mean the advocacy of women's equality with men, sensitivity to the injustices women have suffered, and the resolution that women come into their own without delay" (dikutip dari Allen, Liberated Traditionalism 32). Dalam bukunya yang lain Carmody menulis: "...feminism as a search for justice-a commitment to the full equality of women with men in the possession of humanity” Christian Feminist Theology [Oxford/Cambridge: Blackwell, 1995], 12.

131 Grenz \& Olson, Twentieth..., 201. 
perkembangan spektrum teologi abad ke-20 ini, salah satunya adalah Feminism Theology.

"Dalam segala hal perempuan adalah lebih rendah dibandingkan lakilaki," demikian ungkap sejarawah Yahudi abad pertama Flavius Yosefus. 132 Bahkan dalam doa para Rabbi Yahudi terucap tiga kalimat doa syukur harian yang berbunyi, "Terpujilah Allah karena tidak menciptakanku sebagai orang khafir, terpujilah Dia karena tidak menciptakanku sebagai seorang wanita, dan kiranya terpujilah Dia karena tidak menciptakanku sebagai orang yang tidak berpendidikan."133 Dengan nuansa yang amat diskriminatif, para Rabbi Yahudi abad pertama melarang mengajar atau berkata-kata dengan seorang perempuan. Dalam literatur Hikmat Yahudi bahkan tertulis, "Barangsiapa terlalu banyak berbicara dengan kaum perempuan akan membawa dampak kejahatan atas dirinya, mengingkari ajaran Hukum Taurat dan pada akhirnya akan mewarisi Gehenna (Neraka).134 Alasan utama mengapa kepada para laki-laki diperintahkan agar sedapat mungkin menghindari kaum perempuan karena mereka dipercaya dapat menyesatkan kaum laki-laki, sebagaimana yang tertulis dalam kitab Sirakh 42:13 yang dalam versi NRSVCE135 berbunyi, "From garments cometh a moth and from a woman the iniquities of a man." Dalam kitab yang sama ayat 4 seakan meletakkan konfirmasi mengenai keberadaan kaum laki-laki yang secara intrinsik memang lebih baik dari pada kaum perempuan, "better is the iniquity of a man than a woman doing a good turn." Dalam tradisi Yudaisme, para perempuan sungguh dalam situasi yang terdiskriminasi secara legal-formal; mereka tidak diijinkan memberikan kesaksian dalam pengadilan; bahkan menurut sekolah Rabbinik golongan Hillel membenarkan seorang laki-laki untuk menceraikan istrinya jika ia kedapatan menghanguskan makan malamnya.136

132 Flavius Josephus, Against Apion (Grand Rapids: Kregel Publications, 1974), 622.

133 H. L. Strack and P. Billerbeck, Kommentar zum Neuen Testament aus Talmud und Midrasch (Munchen, 1893), 2:495; dikutip oleh Werner Neuerm dalam, Man and Woman in Christian Perspective (Wheaton, IL: Crossway Books, 1990), 93.

134 M. Aboth 1:5; Ibid.

135 NRSVCE singkatan dari New Revised Standard Version Catholic Edition.

136 R. Nicole, "Biblical Concept of Women," Evangelical Dictionary of Theology, diedit oleh Walter A. Elwell (Grand Rapids: Baker Book House, 1984), 1177. 
Dalam konteks yang sedemikian ironis inilah kemudian kekristenan dilahirkan. Karena itu tidak mengejutkan jika pada masa perkembangan hingga kini tidak sedikit gereja yang masih menerapkan pola-pola diskriminasi dalam pelayanan gerejawi bagi kaum perempuan. McGrath dalam tulisannya memberi catatan mengenai bagaimana kaum perempuan diperlakukan di dalam gereja. Sering kali mereka dianggap sebagai harta milik, sebatas objek belaka, polusi yang membahayakan, dilarang menempati tanggung jawab kepemimpinan gerejawi, menyampaikan khotbah, bahkan mengajar karena secara ekstrim mereka dinilai tidak akan mampu menjadi gambar Allah yang sejati.137

Pada satu segi oleh para penganut feminisme - dengan mengabaikan konteks asali, rasul Paulus dianggap turut memberikan dukungan terhadap langgengnya praktek penjajahan terhadap kaum perempuan oleh gereja Kristen karena melarang aktivitas berbicara dan mengajar dalam gereja. Misalnya, kutipan yang tercatat dalam 1 Korintus 14:34-35 demikian juga dalam 1 Timotius 2:12-16. Dalam tulisannya, stott mengutip ungkapan Tertullianus yang berbunyi, “...You [para perempuan] are the devil's gateway; you are the unsealer of that (forbidden) tree; you are the first deserter of the divine law..."138 Berdasarkan penjelasan ini, maka tidak jarang jika sebuah tanggung jawab kepemimpinan dipengang oleh kaum perempuan sering diidentikkan sebagai pembawa ajaran sesat atau bidat gereja.139 Namun dalam pembahasan teologi dan metode berteologi kaum feminis, dapat dilihat sisi lain dari rasul Paulus yang mereka pahami dalam

137 Alister E. McGrath, ed., The Blackwell Encyclopaedia of Modern Christian Thought (Oxford: Blackwell, 1993) 221. Chrysostom sependapat dengan Agustinus bahwa hanya manusia khususnya laki-laki yang sesuai dengan 'image of God' karena itu laki-laki mempunyai otoritas dan perempuan tidak, 'Then why is the 'man' said to be in the 'image of God' and woman not? ...'image' has rather to do with authority, and this only the man has; woman has it no longer." Janet Martin Soskice, Can A Feminist Call God "Father?, di dalam Speaking the Christian God: The Holy Trinity and Challenge of Feminis, diedit oleh Alvin F. Kimel, Jr., (Michigan: WM B. Eerdmans, 1992), 85.

138 Stott, Issues Facing Christians Today..., 255. Salah satu tokoh teolog Feminis, Rosemary Radford Ruether, mengevaluasi para Bapa gereja dan ahli filsafat seperti Origenes, Agustinus, Socrates, Plato, Philo, dll., mereka hanya menghargai keberadaan kaum laki-laki sebagai 'the Image of God' sedangkan perempuan bukan 'the Image of God', Thomas Aquinas menghargai perempuan sebagai seorang laki-laki yang dilupakan dan Bapa reformasi tidak berusaha mengubah status perempuan di dalam gereja, bahkan Karl Barth pun mengatakan perempuan di dalam perjanjian dengan Allah menduduki tempat nomer dua. Rosemary Radford Ruether, Sexism and God-Talk: Toward A Feminist Theology ${ }_{2}$ (Boston: Beacon, 1983), 193-194.

139 Misalnya dalam tulisan: G. H. Tavard, Woman in Christian Tradition (Notre Dame: University of Notre Dame Press, 1973); Jean Laporte, The Role of Women in Early Christianity (New York: Edwin Mellon, 1982); Ben Witherington III, Women in theEarliest Churches (Cambridge: Cambridge University Press, 1991). 
perspektif positif, khususnya terkait isu kesetaraan gender dalam Galatia $3: 28$.

Memasuki abad pertengahan praktek diskriminasi, perendahan martabat dan stratifikasi status sosial yang tidak manusiawi terhadap kaum perempuan ini mendapat tanggapan yang amat signifikat. Kaum perempuan mulai memanfaatkan kesempatan tersebut untuk secara tegas, terbuka dan disadari mencoba untuk mengaktualisasi diri, salah satunya menjadi para penulis. Puncak perjuangan ide mereka dipicu oleh semangat abad pencerahan yang melahirkan berbagai tulisan buah pena para perempuan, baik itu menjamah isu rohani, filsafat, seni, pendidikan bahkan politik. Dan pada abad ke-20 ini, khususnya di Amerika muncul gerakan feminisme modern yang tercatat dalam buah karya Betty Fredan berjudul "The Feminine Mystique" (1963). 140

\section{Teologi dan Metode Berteologi Gerakan Feminisme Kristen}

Teologi Feminis tidak dapat dipisahkan dari pengaruh, fokus dan tujuan yang tengah diperjuangkan oleh para teolog pembebasan yang mendasarkan konsep teologinya pada konteks alkitabiah yang mengandung pesan pembebasan bagi mereka yang sedang tertindas. Dalam perspektif mereka, peran Allah dianggap sebagai pembela para tertindas, "'God is on the side of the opressed." 141 Gutierrez, misalnya, ia melihat bahwa perjalanan keluarnya bangsa Israel dari Mesir dan perjalanan Kristus membebaskan manusia dari dosa "the Liberator of Sin", menunjukkan secara jelas bahwa Allah adalah "pembebas" bangsa Israel dan umat manusia tertindas di seluruh dunia.142 Letty M. Russel menuliskan responnya, "hear, understand, and accept this message of God's gift of freedom and salvation in their lives."143 Dalam tulisannya, Jewett

140 Begitu berharga dan menyisakan pengaruh yang luar biasa karya tulis tersebut hingga sempat disejajarkan dengan tulisan Charles Darwin yang berjudul The Origin of the Species. Dikutip dalam Donald \& Beverly Allen, Liberated Traditionalism: Men \& Women in Balance (Portland:Multnomah, 1985), 33.

141 Albert Curry, The Reformed Tradition and Liberation Theology, dalam Major Themes in the Reformed Tradition, Donald Mc Kim ed., (Orlando: Wipe \& Stock, 1998), 401.

142 Gustavo Guiterrez, A Theology of Liberation: Historiy, Politics and Salvation, (New York: Orbis, 1973), 155-159.

143 Letty M. Russel, Human Liberation in a Feminist Perspective: A Theology, (Philadelphia: Westminster, 1974), 104. 
menggunakan istilah "The Magna Carta of Humanity" terhadap ungkapan Paulus dalam Galatia 3:28, "Dalam hal ini tidak ada orang Yahudi atau orang Yunani, tidak ada hamba atau orang merdeka, tidak ada laki-laki atau perempuan, karena kamu semua adalah satu di dalam Kristus Yesus."144 Dalam kerangka perjuangan feminisme, ayat ini sering digunakan sebagai landasan teologis. Rasul Paulus dianggap berpihak terhadap kaum feminis karena dalam ayat tersebut tercermin muatan landasan kesetaraan gender, memiliki hak dan kewajiban antara perempuan dan laki-laki baik dalam lingkup keluarga, masyarakat maupun gereja.145

Menarik untuk diselidiki dengan seksama tentang teologi dan metode berteologi para pendukung gerakan feminisme. Karena di satu sisi mereka mengambil ayat-ayat Alkitab untuk mendukung gerakannya, namun di sisi lain mereka menerapkan metode penafsiran yang berbeda. Dalam tulisannya, Fiorenza mengatakan, "Feminist interpretation therefore begins with a hermeneutics of suspicion that applies to both contemporary androcentric interpretations of the Bible and the biblical texts themselves." 146 Dalam redaksi yang sedikit berbeda Ruether menuliskan, "The Bible was shaped by males in a patriarchal culture, so much of its revelatory experiences were interpreted by men from a patriarchal perspective." 147

Tokoh feminis Injili, E. Margaret Howe mengatakan, "one of the more prominent feminist theologians today, notes that this idea is largely based on Old Testament imagery that represents God as "Father," and ignores the Scriptures which typify God as "Mother." The Lord, for example, is portrayed as a nursing mother (Isa. 49:15), midwife (Ps. 22:9-10), and a female homemaker (Ps. 123:2)."148 Karena Allah cenderung dilihat sebagai seorang laki-laki, maka ia berkata seksualitas Allah yang sering ditekankan dari pada kepribadianNya. Penyebutan Allah hanya sebatas laki-laki, 1975), 142.

144 Paul King Jewett, Man as Male and Female (Grand Rapids: William B. Eerdmans Publishing Co.,

145 Ibid.

146 Bread Not Stone: The Challenge of Feminist Biblical Interpretation (Boston: Beacon, 1984), xii.

147 Pamela Dickey Young, Feminist Theology/Christian Theology: In Search of Method (Minneapolis: Fortress, 1990), 116.

148 E. Margaret Howe, "The Positive Case for the Ordination of Women," in Perspectives on Evangelical Theology, diedit oleh Kenneth S. Kantzer and Stanley N. Gundry (Grand Rapids: Baker Book House, 1979), 268. 
sesungguhnya kita sedang di dalam "realm of mythology" membatasi transendensi Ilahi hanya dari segi seksualitasNya.149 Tokoh lain dalam gerakan feminisme yang cukup berpengaruh adalah Mary Daly, seorang Irlandia yang dibesarkan dalam budaya Katolik. Ia menyandang tiga gelar doktor dibidang teologi dan filsafat. Dalam tulisan Ruether mencatat, sementara Daly dalam karya-karya awal ingin melakukan gerakan pembaharuan gereja dari sisi dalam, namun akhir-akhir banyak karya tangannya yang bernuansa feminis dan sepakat untuk mengatakan bahwa gereja telah gagal membawa perubahan sebagaimana mestinya. 150 Teolog bernama David F. Ford memberi komentar bahwa, "Mary Daly has done more than anyone to clarify the problems women have concerning the central core symbolism of Chrisianity, and its effects on their self-understanding and their relationship to God."151 Menurut tokoh-tokoh tersebut di atas, Alkitab tidak boleh diterima begitu saja mengingat sebagai Firman Allah yang tertulis, di dalamnya banyak dipengaruhi unsur-unsur manusiawi (khususnya dominasi kaum laki-laki). Firman Allah memang sempurna namun manusia yang bertindak sebagai penulis tentu banyak memiliki keterbatasan. 152

Terkait dengan metode berteologi kaum feminis, Ruether mengatakan bahwa kekristenan sudah mewarisi suatu sistem dualisme yang sangat kental, yang sudah mengotori dasar pemikiran Alkitab baik secara epistimologi, moral atau ontologi. Ia mengatakan bahwa pemikiran ini sudah meresap sampai ke tulang sumsum tradisi penulisan Alkitab.153 Mereka mencermati berbagai peristiwa pembebasan yang dialami bangsa Israel dari tangan para penindas, demikian juga berbagai nubuat para nabi dengan tema yang sejajar misalnya Yesaya 61:1-2 serta penggenapannya di dalam Kristus yang dicatat dalam Injil Lukas 4:21.

149 Ibid.

150 Rosemary Radford Ruether, Women and Redemption: A Theological History, cetakan ke-2 (Minneapolis: Fortress Press, tt), 217.

151 David F. Ford, The Modern Theologians: An Introduction to Christian theology in the twentieth century, edisi ke-2 (Malden, MA: B. Blackwell, 1997), 242.

152 Russell, "Authority and the Challenge of Feminist Interpretation" dalam Feminist Interpretation of the Bible, 138.

153 Rosemary Radford Ruether, Liberation Theology: Human Hope Confronts Christian History and American Power, (New York: Paulist Press, 1972), 16. 
Menurut Russell, Alkitab adalah firman yang memerdekakan (liberating word). Ada dua prinsip hermeneutik penting yang ingin dipaparkan oleh Russel: pertama, Firman yang Membebaskan (the liberating word), kedua, Firman yang Dibebaskan (the liberated word). The liberated word berarti Alkitab dibebaskan dari cara pandang patriarkhal. Caranya adalah dengan membuang semua budaya patriarkhal yang telah membelenggu teks-teks Alkitab, untuk menemukan berita pembebasan bagi kaum perempuan. 154 Menurutnya tujuan final atau 'ultimate goal' dari gerakan feminis adalah merealisasikan kemanusiaan yang baru, "the final and ultimate goal of liberation (feminist theology) that was the realization of a new humanity."155

Proses pembebasan ini menunjukkan empat penekanan, yaitu: para penafsir teologi pembebasan dan feminis khususnya berjuang secara kritis terhadap teks Alkitab. Mereka harus melakukan rekonstruksi makna secara kreatif, bagi para Feminis, makna ini muncul secara nyata dan jelas melalui komunitas yang berjuang untuk mengatasi dominasi dan "dehumanisasi" atas setengah penduduk dunia. Kabar Baik disampaikan kepada mereka yang miskin dan tersisih sebagai suatu jalan untuk memahami cakrawala pengharapan akan Penciptaan Baru Allah.156 Kaum feminis selain mengembangkan metode hermenutika socio-critical157 demikian juga metode hermeneutika korelasi (A Method of Correlation). 158

Intinya, kaum feminis tidak hanya dipanggil untuk memberitakan berita penghakiman (profetik), namun ada juga unsur mesianisnya, artinya

154 Letty M. Russel, The Liberating Word: A Guide to Non-Sexist Interpretation of the Bible, (Philadelphia: Westminster, 1974), 4-15.

155 Margareth A. Farley, Feminist Consciousness and Interpretation of Scripture, diedit oleh Letty M. Russel, Feminist Interpretation of the Bible, (Philadelphian: The Westminster Press, 1985), 41.

156 Mary A.Kassian, The Feminist Gospel: The Movements to Unite Feminism with the Church, (Illinois: Crossway Books, 1992), 55-56.

157 Hermeneutik 'Socio-critical' adalah metode prinsip penafsiran teks Alkitab yang dibuat untuk mempromosikan dan melegalkan kaum 'kedua' yaitu kaum wanita yang mengalami penindasan dalam kehidupan sosial tatanan masyarakat yang dikuasai oleh sistem 'patriarchal'. Tujuan kritik terhadap prinsip hermeneutik Feminis ini adalah untuk membuka tabir 'pelegalitasan' fungsi sosial yang menindas dan menekan hak-hak wanita yang dipinggirkan. Anthony C. Thiselton, New Horizons in Hermeneutics, (Michigan: Zondervan Publ., 1992), 430.

158 Ruether memiliki pemahaman dan gagasan yang sama dengan Fiorenza seputar, "the androcentric nature of both the Christian texts and the male interpreters of those texts." Umumnya seperti tindakan Fiorenza, Ruether mengedepankan "women's experiences of alienation and being dominated a key to hermeneutics" dengan mengatakan, "“...critical principle of feminist theology is the affirmation and promotion of the full humanity of women." Rosemary Radford Ruether, Feminist Interpretation: A Method of Correlation, diedit oleh Russell, L. M., Feminist Interpretation of the Bible, (Oxford: Basil Blackwell, 1985), 114-116. 
ada kabar "keselamatan" bagi kaum wanita, yakni pembebasan dari ketidakadilan.159 Dalam penyelidikan dan penafsiran secara ketat terhadap teks-teks Alkitab, seperti dalam: Kel. 18:4; Mzm. 22:9-10, 121:1-2, 123:2; U1. 33:26; Yes. 42:14, 49:15, 66:16; dan Luk. 13:34, kaum feminis berpendapat bahwa Allah tidak hanya dimengerti dalam konsep paternal namun juga maternal. Sebagai konsekuensi logisnya adalah penyebutan Allah tidak hanya "Bapa" namun seharusnya juga "Ibu" yang pada akhirnya berakibat terhadap perubahan formula konsep Allah Tritunggal.160

\section{Jalan Tengah yang ditawarkan}

Dua fakta yang muncul di sini adalah subordinansi gender dan usaha pembebasan yang terbilang mengandung resiko serius jika tidak ditawarkan jalan tengah. Tujuan utama ditawarkan jalan tengah ini adalah mengembalikan tujuan mula-mula diciptakannya laki-laki dan perempuan sebagai "penolong yang sepadan" bagi pasangannya, "'ēzer knêgdô" dalam catatan Kej. 2:18. Persatuan antara laki-laki "zākār" dan perempuan " $n{ }^{e} q e b \bar{a}^{h}$ " sebagai perwujudan gambar Allah yang sempurna menekankan bahwa kemanusiaan sejati tercermin dari perpaduan antara maskulinitas dan feminitas. Bagaikan dua sisi dari mata uang demikianlah perpaduan ini adalah setara dan perpaduan kedua gender ini adalah untuk tujuan saling mengisi dan melengkapi demi tercipta kreatifitas dan relasi harmonis. 161 Secara tradisional istilah "penolong yang sepadan" dalam teks Kej. 2:18 dipahami bahwa kaum perempuan adalah pelayan bagi seorang suami dan ternyata tidak sepenuhnya cocok dengan dengan pemahaman istilah "'ēzer knêgdô." Frase ini justru conveys the idea of one who complements as an equal by filling or completing that which is lacking.162 Dalam tulisan

159 Ibid., 117 ,

160 James Leo Garret, Systematic Theology, vol. 1 (Grand Rapids: Wm. B. Eerdmans, 1990), 260261; band. Catherine Mowry LaCugna, "The Baptismal Formula, Feminist Objections, and Trinitarian Theology,"Journal of Ecumenical Studies 26/2 (Spring 1989), 235.

161 Penka Yasua, Perempuan Sumber Dosa? (Malang: Penerbit Dioma, 2011), 86-88.

162 Aída Besançon Spencer, William David Spencer, Steven Tracy, Celestia G. Tracy, Married at the Crossroads: Couple in Conversation About Discipleship, Gender Roles, Decision Making and Intimacy (Downers Grove, Illinois: InterVarsity Press, 2009), 119. 
Besançon tersebut juga dikutip pernyataan Hamilton, thus the new creation [the woman] will neither be a superior or an inferior, but an equal. 163

Menanggapi lebih lanjut dari penjelasan di atas adalah pendapat seorang filsuf Yahudi Martin Buber yang disebut sebagai pemikir dan the father of philosophy of dialogue.164 Dalam konsep Buber, terdapat relasi IThou yang dipahami sebagai hubungan seorang individu dengan individu lain, dengan pasangan bahkan dengan Tuhan; sementara relasi I-It dipahami sebagai hubungan dengan benda, dunia, dan segala sesuatu yang non-manusia.165 Metode dialog adalah hal yang sangat penting dalam hubungan, relasi laki-laki-perempuan dan atau dalam sebuah pernikahan.166 Meskipun menurut Hooks usaha dialogis antar gender tersebut masih menemui kendala subversive dan radical task. Menurutnya dialog yang berkualitas adalah komunikasi antara dua subyek, bukan antara subyek dan obyek. Jika dialog yang terjadi adalah antar subyek, maka itulah yang disebut sebagai humanizing speech, non-domination, reciprocity dan mutuality memungkinkan antara laki-laki dan perempuan to nurture one another, to grow fully and freely.167 Mengaminkan pendapat Buber, Yankelovich berpendapat bahwa dialog merupakan jenis komunikasi yang lebih dalam dari sekadar percakapan biasa, karena sekali lagi di dalam mencakup a genuine openness dari masing-masing pihak dalam menyelesaikan sebuah konflik. 168

\section{Simpulan}

Tidak dapat disangkal bahwa kehadiran gerakan dan teologi pembebasan feminisme telah mewariskan pengaruh yang demikian besar terhadap sejarah perubahan paradigma gereja bahkan kian merambah ke

163 Victor P. Hamilton, The Book of Genesis Chapter 1-17 (Grand Rapids: Eerdmans, 1990), 175.

164 K. Święcicka, Transcendentalizm Husserla a filozofia dialogu, (Wydawnictwo IFiS: PAN, Warsaw, 1993), 82.

165 Sylwia Górzna, "Martin Buber: Father of the Philosophy of Dialogue," dalam European Journal of Science and Theology 10, no. 5 (2014): 46.

166 Lyanne Jacobs, The Therapist as 'Other:' The Patient's Search for Relatedness, Paper dipresentasikan dalam Konferensi: 'Martin Buber's Contribution to the Humanities', October 1991, 8. 1989), 131.

167 Bell Hooks, Talking Back: Thinking Feminist-Thinking Black (Boston, MA: South End Press,

168 Daniel Yankelovich, The Magic of Dialogue: Transforming Conflict Into Cooperation (Rockefeller Center, NY: Touchstone, 1999), 14. 
dalam lingkup yang lebih luas. Teologi feminisme juga telah secara benar menunjukkan kegagalan kaum laki-laki pada umumnya dalam menggenapi rencana Allah terkait dengan tujuan penciptaan. Mengingat kasih dalam kehidupan suami-stri bukankah digambarkan sebagaimana Kristus mengasihi gerejaNya. Berikutnya kontribusi positif dari teologi pembebasan feminisme juga telah berdiri melawan praktek penindasan, perendahan, manipulasi bahkan eksploitasi kaum perempuan.

Dalam perspektif yang lebih luas, pengaruh teologi pembebasan feminisme mempengaruhi seorang bernama Ansary dalam atrikelnya mencatat:

Muslim majority countries have produced more than seven female heads of state, including Benazir Bhutto of Pakistan, Mame Madior Boye of Senegal, Tansu Çiller of Turkey, and Megawati Sukarnoputri of Indonesia. Bangladesh was the first country in the world to have consecutive, elected, female heads of state: Khaleda Zia and Sheikh Hasina 169

Namun demikian, perlu dicatat pula bahwa selain sumbangan besar yang bahkan dapat memicu perubahan paradigma, gerakan dan teologi feminisme juga meninggalkan jejak-jejak problematis. Aliran feminis Kristen ini bergerak dalam sebuah kerangka kerja Kristen namun metode pendekatan feminisme dan teologi anutan mereka secara umum sepenuhnya menggunakan perspektif liberal. Di satu pihak mereka beranggapan bahwa teologi yang tengah dikembangkan ini bersumber dari firman Allah yang diinspirasikan, namun di pihak lain mereka melangkah keluar dari ortodoksi iman Kristen tradisional. Salah satu istilah yang digunakan untuk memberi tanggapan terhadap gerakan dan teologi feminis ini adalah bahwa mereka menerapkan "hermeneutika kecurigaan" atau "hermeneutika menduga-duga" (hermeneutic of suspicion). Maksudnya secara sistematis mereka beranggapan bahwa para penulis kitab yang umumnya kaum laki-laki demikian pula para penafsirnya dengan sengaja

169 Tamim Ansary, Women Who Rule: 10 firsts ,[Artikel on-line]; available from http://encarta.msn.com/encnet/Features/Columns/?article=WomenWhoRule; Internet; diakses pada tanggal 25 November 2017. 
menutupi peran kaum perempuan pada era kekristenan perdana.170 Dalam kerangka kerja hermeneutiknya, kaum feminis juga berusaha untuk menghapuskan sistem kebudayaan (dekulturisasi) yang merupakan ciri kemasyarakatan pada zaman penulisan kitab-kitan suci, yaitu patriaki. Dari metode yang diterapkan maka dapat disandingkan dengan usaha 'demitologisasi' Rudolf Bultmann, yang mana demi memahami berita Injil yang kerugmatis, maka diperlukan langkah mengupas 'mitos' dari Perjanjian Baru, termasuk bagaimana mencoba menyingkapkan tujuan mula-mula di balik mitos-mitos tersebut.171 Metode penafsiran yang kental diwarnai corak eksistensialis 172 ala Matrin Heidegger ini melekat kuat dalam semangat kaum feminis dalam memperjuangkan hak dan berbagai idealismenya.

Secara tegas pandangan yang demikian tentu jauh dari kebenaran. Jika kaum feminis yakin bahwa Alkitab mengandung banyak kesalahan namun mengapa mereka juga menggunakannya sebagai landasan berotoritas untuk prinsip teologis mereka. Seorang bernama Mary Ann Tolbert menulis, "So, one must struggle against God as enemy assisted by God as helper, or one must defeat the Bible as patriarchal authority by using the Bible as liberator. Feminist hermeneutics, then, is profoundly paradoxical."173 Para penganut teologi tradisional (traditionalists), salah satunya Phyllis E. Alsdurf menuangkan pendapatnya yang dimuat dalam majalah Christianity Today, yang meyakini bahwa masuknya gerakan feminisme dalam tubuh injilli adalah salah satu bentuk contoh telah masuknya pengaruh negatif dari trend budaya kekristenan kontemporer. 174

Latar belakang munculnya teologi feminisme harus sungguh-sungguh menjadi awasan cermat, sehingga tidak secara sepihak para responden

170 Kenneth L. Woodward, "Feminism and the Churches," Newsweek, 13 Februari 1989, 61.

171 Harvie M. Conn, Teologia Kontemporer, rev. ed., diterjemahkan oleh Lynne Newell (Malang: Departemen Literatur SAAT, 1999), 51.

172 Prinsip penafsiran eksistensialis menekankan peran utama dari pengertian dan istilah khusus yang dimengerti oleh masyarakat modern dan digunakan secara ketat dalam mendekati tulisan-tulisan dari masa lampau. Ibid.

173 Mary Ann Tolbert, "Defining the Problem: The Bible and Feminst Hermeneutics,” Semeia 28

174 Phyllis E. Alsdurf, "Evangelical Feminists: Ministry Is the Issue," Christianity Today, 21 Juli 1978, 47. 
melontarkan kecaman ketidak setujuan. Fakta penindasan, perendahan, pengabaian, serta tidak sejalannya antara ortodoksi dan ortopraksi gereja dan para pemimpinnya telah menjadi katalisator lahirnya gerakan ini. Memang sangat disayangkan, bahwa di sisi lain, gerakan feminisme ini harus melakukan tindakan ekstrim semisal pengorbanan prinsip iman Kristen ortodoks dan cenderung liberal.

Perlu dicatat bahwa subordinasi kaum perempuan, bukan sematamata langkah yang disengaja oleh para penulis kitab-kitab suci demi tujuan diskriminasi, melainkan akibat langsung dari kejatuhan manusia ke dalam dosa (Kej. 3:16). Sementara tanggung jawab yang Allah berikan kepada lakilaki sebagai kepala merupakan mandat illahi yang telah ditetapkan jauh sebelum peristiwa kejatuhan itu (Kej. 2: $18 \& 23$ ).

Allah Sang Pencipta sesungguhnya telah berlaku amat tepat, karena Adam adalah kepala dan penerima perintah (Kej. 2:16-17), maka dalam peristiwa kejatuhan, Adam pula yang pertama kali diminta pertanggung jawaban (Kej. 3:9 band. Roma 5:12). Motivasi kejatuhan manusia adalah keputusan Adam untuk mengabaikan perintah Allah dan lebih menuruti kemauan istrinya (Kej. 3:17). Jelaslah bahwa penghakiman terhadap Hawa tidak dapat dipahami sebagai landasan pembentukan susunan hierarki dalam tatanan keluarga maupun sosial, apalagi dianggap sebagai landasan pemberlakuan dan pembenaran sistem patriaki yang diskriminan, selain sebagai dampak atau konsekuensi dosa dalam peristiwa kejatuhan.175

Sejarah masa lalu di mana kaum laki-laki pernah gagal dalam menjalankan tanggung jawabnya sebagai kepala dalam pengertian kepemimpinan hingga menghasilkan berbagai bentuk penindasan, perendahan, pengabaian bahkan pelecehan terhadap kaum perempuan tentu tidak dapat begitu saja ditinggalkan. Perlu ada tindakan refleksievaluasi, serta perlu melihat kembali hakikat ideal laki-laki dan perempuan di mata Sang Pencipta. Dalam esainya yang mencerahkan, John Piper menjelaskan hakikat tersebut, "manhood and womanhood are the beautiful handiwork of a good and loving God. Indeed, God "designed our differences 
and they are profound. They are not mere physiological prerequisites for sexual union. They go to the root of our personhood."176 Tulisan tersebut juga telah menginspirasi seorang bernama Elisabeth Elliot dalam komentarnya, "true liberation comes with humble submission to God's original design."177 Meskipun Russell masih bertahan dengan pernyataannya, "Liberation from a patriarchal worldview is never a finished task" namun komentar Elliot di atas layak untuk senantiasa dipertimbangkan.

Pendapat Martin Buber tentang pentingnya dialog antara gender terbukti memberikan jalan keluar terhadap bahaya berlanjutnya praktek dominasi kaum laki-laki terhadap perempuan; namun juga menghindarkan kaum perempuan terhadap resiko gerakan pembebasan feminis yang ekstrim. Dalam perspektif Kristen, memahami dan menempatkan masingmasing gender sesuai tugas dan panggilannya di hadapan Tuhan "'ēzer knêgdô" seperti dalam teks Kej. 2:18, memungkinkan terjadinya entitas komunitarian berdasarkan reciprocity dan equality.

\section{Bibliografi}

Conn, Harvie M. Teologia Kontemporer. Rev. ed. Diterjemahkan oleh Lynne Newell. Malang: Departemen Literatur SAAT, 1999.

Carmody, Denise L. Christian Feminist Theology. Oxford/Cambridge: Blackwell, 1995.

Curry, Albert. The Reformed Tradition and Liberation Theology. Dalam Major Themes in the Reformed Tradition. Diedit oleh Donald Mc Kim. Orlando: Wipe \& Stock, 1998.

Donald \& Beverly Allen. Liberated Traditionalism: Men \& Women in Balance. Portland: Multnomah, 1985. Fakih, Mansour. Analisis Gender dan Transformasi Sosial. Yogyakarta: Pustaka Pelajar, 1997.

Farley, Margareth A. Feminist Consciousness and Interpretation of Scripture. Diedit oleh Letty M. Russel. Feminist Interpretation of the Bible. Philadelphian: The Westminster Press, 1985.

Ford, David F. The Modern Theologians: An Introduction to Christian theology in the twentieth century. Edisi ke-2. Malden, MA: B. Blackwell, 1997.

Garret, James Leo. Systematic Theology. Vol. 1. Grand Rapids: Wm. B. Eerdmans, 1990.

Guiterrez, Gustavo. A Theology of Liberation: Historiy, Politics and Salvation. New York: Orbis, 1973.

Grenz, Stanley J. \& Roger E. Olson. Twentieth Century Theology. Downers Grove: InterVarsity, 1992.

Hamilton, Victor P. The Book of Genesis Chapter 1-17. Grand Rapids: Eerdmans, 1990.

Hooks, Bell. Talking Back: Thinking Feminist-Thinking Black. Boston, MA: South End Press, 1989.

Howe, E. Margaret. "The Positive Case for the Ordination of Women," in Perspectives on Evangelical

Theology. Diedit oleh Kenneth S. Kantzer dan Stanley N. Gundry. Grand Rapids: Baker Book House, 1979.

Jewett, Paul King. Man as Male and Female. Grand Rapids: William B. Eerdmans Publishing Co., 1975.

176 John Piper, What's the Difference (Wheaton, IL: The Council on Biblical Manhood and Womanhood, 1989), 8-9.

177 Ibid., 3. 
Josephus, Flavius. Against Apion. Grand Rapids: Kregel Publications, 1974.

Kassian, Mary A. The Feminist Gospel: The Movements to Unite Feminism with the Church. Illinois: Crossway Books, 1992.

Laporte, Jean. The Role of Women in Early Christianity. New York: Edwin Mellon, 1982.

Martin, Francis. The Feminist Question: Feminist Theology in the Light of Christian Tradition. Grand Rapids: Eerdmans, 1994.

McGrath, Alister E. ed.The Blackwell Encyclopaedia of Modern Christian Thought. Oxford: Blackwell, 1993.

Nicole, R. "Biblical Concept of Women." Evangelical Dictionary of Theology. Diedit oleh Walter A. Elwell. Grand Rapids: Baker Book House, 1984.

Nurjanah, Ismail. Perempuan dalam Pasungan: Bias Laki-laki dalam Penafsiran. Yogyakarta: LkiS, 2003. Ruether, Rosemary Radford. Sexism and God-Talk: Toward A Feminist Theology. Boston: Beacon, 1983. Women and Redemption: A Theological History. Cetakan ke-2. Minneapolis: Fortress Press, tt.

Liberation Theology: Human Hope Confronts Christian History and American Power. New York: Paulist Press, 1972. Feminist Interpretation: A Method of Correlation. Diedit oleh Russell, L. M. Feminist Interpretation of the Bible. Oxford: Basil Blackwell, 1985.

Russel, Letty M. Human Liberation in a Feminist Perspective: A Theology. Philadelphia: Westminster, 1974. . The Liberating Word: A Guide to Non-Sexist Interpretation of the Bible. Philadelphia: Westminster, 1974.

Soskice, Janet Martin. Can A Feminist Call God "Father? Di dalam Speaking the Christian God: The Holy Trinity and Challenge of Feminis. Diedit oleh Alvin F. Kimel, Jr. Michigan: WM B. Eerdmans, 1992.

Spencer, Aída Besançon. Et al. Married at the Crossroads: Couple in Conversation About Discipleship, Gender Roles, Decision Making and Intimacy. Downers Grove, Illinois: InterVarsity Press, 2009.

Stott, John. Issues Facing Christians Today: New Perspectives on Social and Moral Dilemmas. London: Marshall Pickering, 1990.

Strack, H. L. and P. Billerbeck. Kommentar zum Neuen Testament aus Talmud und Midrasch. Munchen, 1893. 2:495. Dikutip oleh Werner Neuerm dalam, Man and Woman in Christian Perspective. Wheaton, IL: Crossway Books, 1990.

Święcicka, K. Transcendentalizm Husserla a filozofia dialogu. Wydawnictwo IFiS: PAN, Warsaw, 1993. Tavard, G. H. Woman in Christian Tradition. Notre Dame: University of Notre Dame Press, 1973. Thiselton, Anthony C. New Horizons in Hermeneutics. Michigan: Zondervan Publishings, 1992. Witherington III, Ben. Women in theEarliest Churches. Cambridge: Cambridge University Press, 1991. Yasua, Penka. Perempuan Sumber Dosa? Malang: Penerbit Dioma, 2011.

Yankelovich, Daniel. The Magic of Dialogue: Transforming Conflict Into Cooperation. Rockefeller Center, NY: Touchstone, 1999.

Young, Pamela Dickey. Feminist Theology/Christian Theology: In Search of Method. Minneapolis: Fortress, 1990.

\section{Majalah, Journal dan Esai}

Alsdurf, Phyllis E. "Evangelical Feminists: Ministry Is the Issue." Christianity Today. 21 Juli 1978, 47.

Bread Not Stone: The Challenge of Feminist Biblical Interpretation. Boston: Beacon, 1984, xii.

Górzna, Sylwia. "Martin Buber: Father of the Philosophy of Dialogue.” Dalam European Journal of Science and Theology 10, no. 5 (2014): 46.

Jacobs, Lyanne. The Therapist as 'Other:' The Patient's Search for Relatedness, Paper dipresentasikan dalam Konferensi: 'Martin Buber's Contribution to the Humanities', October 1991.

LaCugna, Catherine Mowry. "The Baptismal Formula, Feminist Objections, and Trinitarian Theology."Journal of Ecumenical Studies 26:2 (Spring 1989): 235.

Piper, John. What's the Difference. Wheaton, IL: The Council on Biblical Manhood and Womanhood, 1989. 
Tolbert, Mary Ann. "Defining the Problem: The Bible and Feminst Hermeneutics.” Semeia 28, 1983.

Wenham, G. J. "The Ordination of Women: Why Is It So Divisive?" The Churchman 92, 1978.

Woodward, Kenneth L. "Feminism and the Churches." Newsweek, 13 Februari 1989, 61.

\section{Internet}

Ansary, Tamim. Women Who Rule: 10 firsts. [Artikel on-line]. Available from http://encarta.msn.com/encnet/Features/Columns/?article=WomenWhoRule. Internet. Diakses pada tanggal 25 November 2017.

Feminist Theology. [Artikel on-line]. Available from http://en.wikipedia.org/wiki/Feminist_theology. Internet. Diakses pada tanggal: 25 November 2017.

Fiorenza, Elizabeth Schüssler. Feminist Theology As A Critical Theology of Liberation. University of Notre Dame, tt. 607. [Artikel on-line]. Available from http://www.ts.mu.edu/readers/content/pdf/36/36.4/36.4.2.pdf. Diakses pada tanggal: 30 Oktober 2017.

Ga, Ester Mariani. "Partisipasi Politik Perempuan : Antara Kewajiban dan Perjuangan Memperoleh Hak. Bina Darma. 1997. [Artikel on-line]. Available from http: isjd.pdii.lipi.go.id/admin/journal/5415978996.pdf. Internet. Diakses pada tanggal: 24 November 2017.

Inter Parlementary Union, 2012. [Artikel on-line]. Available from (http://www.ipu.org/wmn-e/classif.htm. Diakses pada tanggal: 24 November 2017.

Mahendra, Dhimas Wisnu. "Mengenal dan Memahami Pemikiran Ibu Kita Kartini Melalui Tulisan-tulisannya." 20 April 2012 [Artikel on-line]. Available from http://sosok.kompasiana.com/2012/04/20/mengenaldan-memahami-pemikiran-ibu-kita-kartini-melalui-tulisan-tulisannya-456880.html. Internet. Diakses pada tanggal: 25 Oktober 2017.

Sahkan RUU Penghapusan Kekerasan dengan Memperhatikan Perlindungan Korban Seksual dengan Memperhatikan Perlindungan Korban. [Artikel on-line]. Available from https://www.komnasperempuan.go.id/reads-peluncuran-kampanye-16-hari-anti-kekerasan-terhadapperempuan-tahun-2017. Internet. Diakses pada tanggal: 24 November 2017.

Biografi singkat

Penulis menyelesaikan studi pascasarjana dalam bidang teologi di STT Satyabhakti, dan kini sebagai pengajar tetap. Saat ini sedang mempersiapkan diri untuk menempuh studi tingkat doktoral. 